\title{
FOLIAR FERTILIZATION WITH COMMERCIAL LIQUID FERTILIZER FOR IMPROVING GROWTH AND QUALITY OF SEASHORE PASPALUM TURF
}

\author{
A.S. Tawila ; T.M. Noor El-Deen ${ }^{* *}$; Boshra A. El-Sayed ${ }^{* *}$ and S.M. Shahin ${ }^{*}$ \\ * Botanical Gardens Res. Dept., Hort. Res. Inst., ARC, Giza, Egypt. \\ ** Ornamental Plants and Landscape Gardening Res. Dept., Hort. Res. Inst., ARC, Giza, Egypt.
}

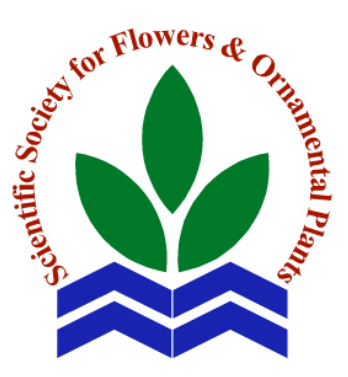

Scientific J. Flowers \& Ornamental Plants, 2(1):85-92 (2015).

Received: $10 / 12 / 2014$

Revised by: Prof. Dr. E.S. Nofal, Kafr El-Sheikh Univ.

Prof. Dr. A.Z. Sarhan, Cairo Univ.
ABSTRACT: An investigation was conducted under the open field condition at the Experimental Farm of Hort. Res. Inst., ARC, Giza, Egypt during 2013 and 2014 seasons to study the effect of some commercial liquid fertilizers; super blue-green (SBG) at the rates of 1 and $3 \mathrm{ml} / \mathrm{l}$, Kalsin-A (K-A) at the rate of $1 \mathrm{ml} / \mathrm{l}$ and the combinations between the two levels of SBG and that of K-A on growth, density and chemical composition of seashore paspalum (Paspalum vaginatum Swartz) planted in 40-cm-diameter plastic pots filled with about $6 \mathrm{~kg}$ of sand and clay mixture (1:1, by volume) when applied as a foliar spray, 5 times with one month interval. The control plants were sprayed with tap water only.

The obtained results indicated that all single and combined treatments used in the study markedly improved all vegetative growth traits of the fertilized plants with various significant differences compared to control plants in the two seasons. Among the sole treatments, $\mathrm{SBG}$ at $3 \mathrm{ml} / 1$ treatment was the superior, whereas the same fertilizer and K-A one at $1 \mathrm{ml} / \mathrm{l}$ for each were the inferior. On the other hand, combined treatments induced a more improvement in all vegetative growth parameters than the individual ones, but the prevalence in both seasons was for SBG at $3 \mathrm{ml} / 1+\mathrm{K}-\mathrm{A}$ at $1 \mathrm{ml} / \mathrm{l}$ combined one, which gave the highest records at all. A similar trend was also observed as well regarding the leaf content of chlorophyll a, b, carotenoids, N, P, K, Ca and total soluble sugars except for $1 \mathrm{ml} / 1 \mathrm{~K}$ A treatment which gave the highest content of $\mathrm{Ca}$ among the sole treatments, and the increment in total soluble sugars content was attained by the individual fertilization treatments as was not significant relative to control in both seasons. In addition, the total indole content was significantly increased in response to the different treatments used in this study to reach the maximum by the two combined treatments. The opposite was the right concerning the content of total phenols.

Accordingly, it can be advised to spray the herb of seashore paspalum turf with a combination of super blue-green liquid fertilizer at $3 \mathrm{~m} / 1$ plus Kalsin-A at $1 \mathrm{ml} / \mathrm{l}$, five times with one month interval to obtain the best growth, coverage and colour.

Key words: Seashore paspalum, commercial liquid fertilizers, turfgrass, color, density, vegetative growth. 


\section{A.S. Tawila et al.}

\section{INTRODUCTION}

Seashore paspalum (Paspalum vaginatum Swartz) is a succulent warm-season turf type grasses that belongs to Fam. Graminae, but it retains a healthy appearance all year-round, unlike bermudagrass that tends to off-colour during cooler months and short days (Hulxey et al., 1992). It is easily propagated by cuttings and pre-prepared rolls, and fast spreads with lateral growing stems called stolons. It makes an attractive perennial turf in tropical and subtropical areas and can tolerate irrigation water with high salinity levels, withstand mowing, treading as well as wear and tear (Morton, 1974).

Turf grass plants usually undergo many stresses, i.e., they are crowded together and compete with each other for water and nutrients. They are regularly mowed and their clippings are often removed. So, they must be well fertilized to face these competition and the un-natural demands placed on them. With proper fertilization, the lawn will maintain good colour, density and vigour and will not be easily succumb to insects, weeds or diseases (Peacock et al., 1985). Foliar fertilization may be one of the quick and practical methods for applying fertilizers as solutions are easily absorbed by leaves. Through the equal distribution of the solution all over the plants. In this concern, El-Sayed (2012) found that spraying the foliage of seashore paspalum with humic acid liquid fertilizer at $20 \mathrm{ml} / 1$ + Oligo-X liquid algae extract at $1.5 \mathrm{ml} / 1$ gave the tallest plants, No. plants/pot, covering rate, herb fresh and dry weights, as well as leaf content of pigments, total soluble sugars, indoles an phenols. Similar results were also elicited by Trenholm and Unruh (2009) on Paspalum notatum, Rimia et al. (2013) on bermudagrass and seashore paspalum, Pompeianoa et al. (2014) on Cynodon dactylon $\times C$. transvaalensis "Tifway", Zoysia japonica "Meyer" and Paspalum vaginatum "Salam".

Now, our local market is full of several commercial fertilizers that supply the plants with various nutrients and compounds essential for increasing growth, production and quality. So, examining the efficacy of these commercial products practically by scientists and researchers may be valid in this concern. This is the main goal of such trial.

\section{MATERIALS AND METHODS}

The present work was carried out under the full sun at the Experimental Farm of Hort. Res. Inst., ARC, Giza, Egypt throughout the two successive seasons of 2013 and 2014 to reveal the response of seashore paspalum grass to foliar spraying with some commercial liquid fertilizers.

Thus, circles from pre-prepared rolles of seashore paspalum (Paspalum vaginatum Swartz) at a radius of $10 \mathrm{~cm}$ (their fresh weights ranged between 90-100 g) were carefully taken and planted on April, $1^{\text {st }}$ for each season in the center of 40-cm-diameter plastic pots (one piece/pot) filled with about $6 \mathrm{~kg}$ of an equal mixture of sand and clay. The physical and chemical analysis of the used sand and clay in the two seasons are shown in Table (1).

Table 1. The physical and chemical analyses of the used sand and clay during 2013 and 2014 seasons.

\begin{tabular}{|c|c|c|c|c|c|c|c|c|c|c|c|c|c|c|}
\hline \multirow[b]{2}{*}{ Soil type } & \multirow[b]{2}{*}{ Seasons } & \multicolumn{4}{|c|}{ Particle size distribution (\%) } & \multirow[b]{2}{*}{ S.P. pH } & \multirow{2}{*}{$\begin{array}{c}\text { E.C. } \\
(\mathrm{dS} / \mathrm{m})\end{array}$} & \multicolumn{4}{|c|}{ Cations (meq/l) } & \multicolumn{3}{|c|}{ Anions (meq/l) } \\
\hline & & $\begin{array}{c}\text { Coarse } \\
\text { sand }\end{array}$ & $\begin{array}{l}\text { Fine } \\
\text { sand }\end{array}$ & Silt & Clay & & & $\mathbf{C a}^{++}$ & $\mathbf{M g}^{++}$ & $\mathbf{N a}^{+}$ & $\mathbf{K}^{+}$ & $\mathrm{HCO}_{3}^{-}$ & $\mathrm{Cl}^{-}$ & $\mathrm{SO}_{4}^{--}$ \\
\hline \multirow{2}{*}{ Sand } & 2013 & 89.03 & 2.05 & 0.40 & 8.52 & 23.007 .92 & 3.72 & 7.50 & 1.63 & 33.60 & 0.50 & 3.20 & 22.00 & 18.03 \\
\hline & 2014 & 90.10 & 1.95 & 0.50 & 7.45 & 22.867 .89 & 3.75 & 19.42 & 8.33 & 7.20 & 0.75 & 1.60 & 7.00 & 27.10 \\
\hline \multirow{2}{*}{ Clay } & 2013 & 7.54 & 22.28 & 30.55 & 39.63 & 55.008 .17 & 2.26 & 7.82 & 2.12 & 15.40 & 0.75 & 6.60 & 8.20 & 11.29 \\
\hline & 2014 & 7.64 & 22.50 & 30.15 & 39.71 & 51.008 .09 & 2.38 & 7.50 & 2.20 & 15.50 & 0.75 & 6.78 & 8.02 & 11.15 \\
\hline
\end{tabular}


After about 50 days from planting (on May, $\left.20^{\text {th }}\right)$, the following fertilization treatments were applied before cut as a foliar spray till the solution was run-off, five times with one month interval (till $20^{\text {th }}$ of September of each season):

1- No fertilization, referred to as control, as the plants were sprayed with tap water.

2- Super blue-green, a commercial liquid product that contains amino acids, vitamins, minerals and auxins extracted from algae at the rates of 1 and $3 \mathrm{ml} / \mathrm{l}$.

3- Kalsin-A, a commercial liquid fertilizer that contains calcium $(15 \%)$, chelated acids $(12 \%)$, citric acid $(4 \%)$ and boron $(2 \%)$ at the rate of $1 \mathrm{ml} / 1$.

The previous 2 products were produced by General Organization for Agric. Equalization Fund (G.O.A.E.F.), Biofertilizer Unit, ARC, Ministry of Agriculture and Land Reclamation.

4- Each level of super blue-green was combined with that of Kalsin-A to formalize the following 2 combinations:

a. Super blue-green at $1 \mathrm{ml} / 1+$ Kalsin-A at 1 $\mathrm{ml} / \mathrm{l}$.

b. Super blue-green at $3 \mathrm{ml} / 1+$ Kalsin-A at 1 $\mathrm{ml} / \mathrm{l}$.

After 2 months from planting (on June, $\left.1^{\text {st }}\right)$, the first cut was handily done with a very sharp stainless steal cutter leaving stubbles with 1 inch long, while other 4 cuts were carried out monthly thereafter. This means that fertilization treatments were applied before each cut by about 10 days. The pots were arranged in a completely randomized design (Mead et al., 1993), with 3 replicates for each treatment, as each replicate contained 5 pots.

Before each cut in the two seasons, plant height $(\mathrm{cm})$ was recorded, while number of plants/pot and fresh and dry weight ( $\mathrm{g}$ ) of the resulted clippings after mowing were determined after each cut. Moreover, the covering rate as percentage was evaluated using the method described by Mahdi (1953). However, the means of each parameter abovenamed in the five taken cuts were collected and expressed in the tables as an average for all cuts. In fresh leaf samples taken from the last cut (on October, $1^{\text {st }}$ ), photosynthetic pigments (chlorophyll a, b and carotenoids, as $\mathrm{mg} / \mathrm{g}$ f.w.), as well as total indoles and total phenols $(\mathrm{mg} / 100 \mathrm{~g}$ f.w.) were measured according to the methods of Saric et al. (1967), A.O.A.C (1990) and William et al. (1965), respectively, while in dry samples, the percentages of nitrogen (Pregl, 1945), phosphorus (Cottenie at al., 1982), potassium (Jackson, 1973) and total soluble sugars (Dubois et al., 1966) were measured.

Data were then tabulated and subjected to analysis of variance using SAS Institute Program (1994), followed Duncan's Multiple Range Test (Duncan, 1955), to detect the significancy among various treatments.

\section{RESULTS AND DISCUSSION}

\section{Effect of fertilization treatments on:}

\section{1- Vegetative growth parameters:}

As shown in Tables (2 and 3), it can be concluded that all individual and combined treatments used in this trial noticeably improved all vegetative growth measurements of the fertilized plants, expressed as plant height $(\mathrm{cm})$, No. plants/pot, covering rate (\%) and fresh and dry weights (g) of clippings/pot, with various significant differences when compared to control in the two seasons. Among the sole treatments, super blue-green at $3 \mathrm{ml} / 1$ treatment was the superior, whilst the same fertilizer and Kalsin-A at $1 \mathrm{ml} / \mathrm{l}$ for each were the inferior. The combining between every level of SBG fertilizer and that of K-A caused an additional improvement in all traits abovenamed, but the dominance in both seasons was for SBG at $3 \mathrm{~m} / \mathrm{l}+\mathrm{K}-\mathrm{A}$ at $1 \mathrm{ml} / \mathrm{l}$ combination which scored the highest means at all. 
Table 2. Effect of fertilization treatments on plant height, number of plants/pot and covering rate of Paspalum vaginatum Swartz plants during 2013 and 2014 seasons.

\begin{tabular}{|c|c|c|c|c|c|c|}
\hline \multirow{2}{*}{ Treatments } & \multicolumn{2}{|c|}{ Plant height (cm) } & \multicolumn{2}{|c|}{ No. of plants/pot } & \multicolumn{2}{|c|}{ Covering rate (\%) } \\
\hline & 2013 & 2014 & 2013 & 2014 & 2013 & 2014 \\
\hline Control & $30.44 \mathrm{c}$ & $29.02 \mathrm{c}$ & $30.33 c$ & $32.73 \mathrm{c}$ & $74.76 \mathrm{~d}$ & $81.75 \mathrm{e}$ \\
\hline SBG at $1 \mathrm{ml} / \mathrm{l}$ (A) & $32.04 \mathrm{bc}$ & $29.82 \mathrm{c}$ & $31.50 \mathrm{c}$ & $34.02 \mathrm{c}$ & $78.75 \mathrm{~cd}$ & $86.00 \mathrm{~d}$ \\
\hline SBG at $3 \mathrm{ml} / \mathrm{l}(\mathrm{B})$ & $33.22 \mathrm{~b}$ & $31.63 b$ & $33.75 b$ & $36.51 \mathrm{~b}$ & $84.33 b c$ & $91.25 \mathrm{c}$ \\
\hline $\mathrm{K}-\mathrm{A}$ at $1 \mathrm{ml} / \mathrm{l}(\mathrm{C})$ & $31.50 \mathrm{bc}$ & $29.47 \mathrm{c}$ & $33.00 \mathrm{~b}$ & $35.63 b c$ & $81.68 \mathrm{c}$ & $89.00 \mathrm{~cd}$ \\
\hline $\mathbf{A}+\mathbf{C}$ & $32.75 b$ & $32.43 \mathrm{ab}$ & 35.33ab & $38.49 \mathrm{ab}$ & $88.31 \mathrm{~b}$ & $96.00 \mathrm{~b}$ \\
\hline $\mathbf{B}+\mathbf{C}$ & $35.65 \mathrm{a}$ & $33.25 \mathrm{a}$ & $37.48 \mathrm{a}$ & $40.50 \mathrm{a}$ & $93.78 \mathrm{a}$ & $100.00 \mathrm{a}$ \\
\hline
\end{tabular}

- SBG = Suber blue-green, and K-A = Kalsin-A.

- Means within a column having the same letters are not significantly different according to Duncan's Multiple Range Test (DMRT) at 5\% level.

Table 3. Effect of fertilization treatments on fresh and dry weights of Paspalum vaginatum Swartz clippings/pot during 2013 and 2014 seasons.

\begin{tabular}{|c|c|c|c|c|}
\hline \multirow{2}{*}{ Treatments } & \multicolumn{2}{|c|}{ Fresh weight (g) } & \multicolumn{2}{|c|}{ Dry weight (g) } \\
\hline & 2013 & 2014 & 2013 & 2014 \\
\hline Control & $33.45 \mathrm{e}$ & $31.87 \mathrm{~d}$ & $15.39 d$ & $14.68 \mathrm{e}$ \\
\hline SBG at $1 \mathrm{ml} / \mathrm{l}(\mathrm{A})$ & $34.89 \mathrm{de}$ & $37.00 \mathrm{c}$ & $16.83 c$ & $17.81 d$ \\
\hline SBG at $3 \mathrm{ml} / \mathrm{l}(\mathrm{B})$ & $40.56 c$ & $42.33 b$ & $19.94 b c$ & $20.75 c$ \\
\hline $\mathrm{K}-\mathrm{A}$ at $1 \mathrm{ml} / \mathrm{l}(\mathrm{C})$ & $36.67 d$ & $38.12 \mathrm{c}$ & $17.50 \mathrm{c}$ & $18.21 \mathrm{~cd}$ \\
\hline $\mathbf{A}+\mathbf{C}$ & $44.71 b$ & $46.55 \mathrm{ab}$ & $22.36 b$ & $23.26 \mathrm{~b}$ \\
\hline $\mathbf{B}+\mathbf{C}$ & $48.03 \mathrm{a}$ & $47.96 \mathrm{a}$ & $26.39 a$ & $26.40 \mathrm{a}$ \\
\hline
\end{tabular}

- SBG = Suber blue-green, and K-A = Kalsin-A.

- Means within a column having the same letters are not significantly different according to Duncan's Multiple Range Test (DMRT) at 5\% level.

This may be ascribed to lump benefits of the two used fertilizers in providing the sod plants with $\mathrm{Ca}$ that is necessary for strengthening cell membranes and regulating $\mathrm{Na}, \mathrm{Mg} / \mathrm{Ca}, \mathrm{K}$ ratio, with minerals essential for healthy growth (Mengel and Kirkby, 1979), with auxins that activate vital processes and in turn increase vegetative and root growth (Kenneth, 1979), as well as with vitamins and amino acids which directly influence the physiological activities in plant growth and development (Datir et al., 2012). In this connection, Pompeianoa et al. (2014) stated that Paspalum vaginatum "Salam" showed a positive response to $\mathrm{N}$ fertilization in terms of root and horizontal stem (rhizomes and stolons) dry weight. On Paspalum notatum, Trenholm and Unruh (2009) noticed that the best growth performance occurring from $\mathrm{N}$ at 2-3 $\mathrm{Ib}$ per $1000 \mathrm{ft}^{2}$ annualy.

\section{2- Chemical composition:}

Data presented in Tables (4, 5 and 6) exhibit that the leaf content of chlorophyll a, b and carotenoids (mg/g f.w.), as well as the percentages of $\mathrm{N}, \mathrm{P}, \mathrm{K}, \mathrm{Ca}$ and total soluble sugars were significantly increased in response to the different fertilization treatments used with few exceptions when compared to their content in the leaves of control plants in both seasons. The individual application of super blue-green at $1 \mathrm{ml} / 1$ treatment gave values of the above mentioned constituents relatively near to those of Kalsin-A at $1 \mathrm{ml} / 1$ with nonsignificant differences between them in most cases of the two seasons. However, SBG at 3 $\mathrm{ml} / \mathrm{l}$ treatment recorded higher values than those of the two individual treatments. Among the sole treatments, $\mathrm{K}-\mathrm{A}$ at $1 \mathrm{ml} / \mathrm{l}$ registered the highest $\mathrm{Ca}$ content in both seasons. Moreover, increasing of total soluble sugars 
Table 4. Effect of fertilization treatments on pigments content (mg/g f.w.) in the leaves of Paspalum vaginatum Swartz plants during 2013 and 2014 seasons.

\begin{tabular}{lcccccc}
\hline \multicolumn{1}{c}{ Treatments } & \multicolumn{2}{c}{ Chlorophyll (a) } & \multicolumn{2}{c}{ Chlorophyll (b) } & \multicolumn{2}{c}{ Carotenoids } \\
& $\mathbf{2 0 1 3}$ & $\mathbf{2 0 1 4}$ & $\mathbf{2 0 1 3}$ & $\mathbf{2 0 1 4}$ & $\mathbf{2 0 1 3}$ & $\mathbf{2 0 1 4}$ \\
\hline Control & $0.626 \mathrm{e}$ & $0.609 \mathrm{~d}$ & $0.309 \mathrm{c}$ & $0.332 \mathrm{c}$ & $0.356 \mathrm{bc}$ & $0.301 \mathrm{c}$ \\
SBG at 1 ml/l (A) & $0.762 \mathrm{~d}$ & $0.721 \mathrm{~cd}$ & $0.398 \mathrm{bc}$ & $0.384 \mathrm{bc}$ & $0.401 \mathrm{~b}$ & $0.349 \mathrm{bc}$ \\
SBG at 3 ml/l (B) & $0.969 \mathrm{~b}$ & $0.896 \mathrm{c}$ & $0.478 \mathrm{~b}$ & $0.467 \mathrm{~b}$ & $0.457 \mathrm{ab}$ & $0.392 \mathrm{~b}$ \\
K-A at 1 $\mathbf{~ m l} / \mathbf{l}$ (C) & $0.815 \mathrm{c}$ & $0.659 \mathrm{~d}$ & $0.402 \mathrm{bc}$ & $0.371 \mathrm{bc}$ & $0.303 \mathrm{c}$ & $0.300 \mathrm{c}$ \\
A + C & $1.506 \mathrm{a}$ & $1.518 \mathrm{~b}$ & $0.743 \mathrm{a}$ & $0.699 \mathrm{a}$ & $0.485 \mathrm{a}$ & $0.510 \mathrm{a}$ \\
B + C & $1.687 \mathrm{a}$ & $1.823 \mathrm{a}$ & $0.833 \mathrm{a}$ & $0.786 \mathrm{a}$ & $0.496 \mathrm{a}$ & $0.543 \mathrm{a}$ \\
\hline
\end{tabular}

- SBG = Suber blue-green, and K-A = Kalsin-A.

- Means within a column having the same letters are not significantly different according to Duncan's Multiple Range Test (DMRT) at 5\% level.

Table 5. Effect of fertilization treatments on nitrogen, phosphorus, potassium and calcium \% of Paspalum vaginatum Swartz plants during 2013 and 2014 seasons.

\begin{tabular}{lcccccccc}
\hline \multicolumn{1}{c}{ Treatments } & \multicolumn{2}{c}{$\mathbf{N}(\%)$} & \multicolumn{2}{c}{ P (\%) } & \multicolumn{2}{c}{ K (\%) } & \multicolumn{2}{c}{ Ca (\%) } \\
& $\mathbf{2 0 1 3}$ & $\mathbf{2 0 1 4}$ & $\mathbf{2 0 1 3}$ & $\mathbf{2 0 1 4}$ & $\mathbf{2 0 1 3}$ & $\mathbf{2 0 1 4}$ & $\mathbf{2 0 1 3}$ & $\mathbf{2 0 1 4}$ \\
\hline Control & $1.98 \mathrm{~d}$ & $1.79 \mathrm{~d}$ & $0.149 \mathrm{c}$ & $0.137 \mathrm{c}$ & $1.32 \mathrm{~d}$ & $1.40 \mathrm{~d}$ & $0.480 \mathrm{e}$ & $0.509 \mathrm{e}$ \\
SBG at 1 ml/l (A) & $2.16 \mathrm{c}$ & $1.95 \mathrm{~cd}$ & $0.173 \mathrm{bc}$ & $0.151 \mathrm{bc}$ & $1.65 \mathrm{c}$ & $1.76 \mathrm{bc}$ & $0.552 \mathrm{~d}$ & $0.581 \mathrm{~d}$ \\
SBG at 3 ml/l (B) & $2.38 \mathrm{bc}$ & $2.11 \mathrm{c}$ & $0.198 \mathrm{~b}$ & $0.184 \mathrm{~b}$ & $1.78 \mathrm{bc}$ & $1.89 \mathrm{~b}$ & $0.550 \mathrm{~d}$ & $0.590 \mathrm{~d}$ \\
K-A at 1 $\mathbf{~ m l} / \mathbf{l} \mathbf{( C )}$ & $2.07 \mathrm{c}$ & $1.86 \mathrm{~d}$ & $0.162 \mathrm{c}$ & $0.148 \mathrm{bc}$ & $1.60 \mathrm{c}$ & $1.66 \mathrm{c}$ & $0.764 \mathrm{c}$ & $0.810 \mathrm{c}$ \\
$\mathbf{A}+\mathbf{C}$ & $2.76 \mathrm{~b}$ & $2.43 \mathrm{~b}$ & $0.214 \mathrm{ab}$ & $0.197 \mathrm{ab}$ & $1.91 \mathrm{~b}$ & $2.03 \mathrm{ab}$ & $1.190 \mathrm{~b}$ & $1.176 \mathrm{~b}$ \\
B + C & $3.10 \mathrm{a}$ & $3.03 \mathrm{a}$ & $0.233 \mathrm{a}$ & $0.214 \mathrm{a}$ & $2.25 \mathrm{a}$ & $2.14 \mathrm{a}$ & $1.420 \mathrm{a}$ & $1.285 \mathrm{a}$ \\
\hline
\end{tabular}

- SBG = Suber blue-green, and K-A = Kalsin-A.

- Means within a column having the same letters are not significantly different according to Duncan's Multiple Range Test (DMRT) at $5 \%$ level.

Table 6. Effect of fertilization treatments on total soluble sugars, indoles and phenols content in the leaves of Paspalum vaginatum Swartz plants during 2013 and 2014 seasons.

\begin{tabular}{|c|c|c|c|c|c|c|}
\hline \multirow[t]{2}{*}{ Treatments } & \multicolumn{2}{|c|}{$\begin{array}{c}\text { Total soluble sugars } \\
(\%)\end{array}$} & \multicolumn{2}{|c|}{ Total indoles (mg/100 g f.w.) } & \multicolumn{2}{|c|}{$\begin{array}{l}\text { Total phenoles } \\
\text { (mg/100 g f.w.) }\end{array}$} \\
\hline & 2013 & 2014 & 2013 & 2014 & 2013 & 2014 \\
\hline Control & $9.38 \mathrm{c}$ & $10.87 \mathrm{c}$ & $0.003 \mathrm{c}$ & $0.003 \mathrm{~d}$ & $0.020 \mathrm{a}$ & $0.023 a$ \\
\hline SBG at $1 \mathrm{ml} / \mathrm{l}(\mathrm{A})$ & $10.89 \mathrm{c}$ & $11.56 \mathrm{c}$ & $0.011 \mathrm{~b}$ & $0.008 \mathrm{c}$ & $0.014 b$ & $0.019 \mathrm{ab}$ \\
\hline $\mathrm{SBG}$ at $3 \mathrm{ml} / \mathrm{l}(\mathrm{B})$ & $12.67 b c$ & $12.84 \mathrm{bc}$ & $0.019 \mathrm{ab}$ & $0.013 b$ & $0.016 \mathrm{ab}$ & $0.016 b c$ \\
\hline $\mathrm{K}-\mathrm{A}$ at $1 \mathrm{ml} / \mathrm{l}(\mathrm{C})$ & $10.00 \mathrm{c}$ & $11.09 \mathrm{c}$ & $0.008 \mathrm{~b}$ & $0.005 \mathrm{~cd}$ & $0.019 \mathrm{a}$ & $0.018 b$ \\
\hline $\mathbf{A}+\mathbf{C}$ & $13.60 \mathrm{~b}$ & $13.46 b$ & $0.021 \mathrm{a}$ & $0.017 \mathrm{a}$ & $0.013 b$ & $0.011 \mathrm{c}$ \\
\hline $\mathbf{B}+\mathbf{C}$ & $16.96 \mathrm{a}$ & $15.69 \mathrm{a}$ & $0.023 \mathrm{a}$ & $0.018 \mathrm{a}$ & $0.011 \mathrm{c}$ & $0.011 \mathrm{c}$ \\
\hline
\end{tabular}

- SBG = Suber blue-green, and K-A = Kalsin-A.

- Means within a column having the same letters are not significantly different according to Duncan's Multiple Range Test (DMRT) at 5\% level.

content was only significant by the two combined treatments.

On the other hand, combining between SBG liquid fertilizer at any level and K-A one at $1 \mathrm{ml} / \mathrm{l}$ caused more increment in such constituents than the individual application, but the prevalence in both seasons was for SBG at $3 \mathrm{ml} / 1$ and $\mathrm{K}-\mathrm{A}$ at $1 \mathrm{ml} / 1$ combination which recorded the utmost high content of various components abovenemed over control and all other treatments. This may be reasonable because of the synergistic effect of both fertilizers in providing the sod plants with their 


\section{A.S. Tawila et al.}

requirements of nutrients, vitamins, auxins and amino acids which directly share in vital processes occurred in plant tissues (Kenneth, 1979). In this regard, Rimia et al. (2013) mentioned that fall-applied $\mathrm{N}$ enhanced greenness of Bemudgrass and seashore paspalum and extended fall colour retention of them.

As for total indoles and total phenols content (mg/100 g f.w.), data presented in Table (6) show that total indoles content was significantly increased as a result of applying the different fertilization treatments used in this work to reach the maximum by the two combined treatments, with the mastery of 3 $\mathrm{ml} / 1 \mathrm{SBG}+1 \mathrm{ml} / \mathrm{l} \mathrm{K}$-A combined one which recorded the highest content in the $1^{\text {st }}$ and $2^{\text {nd }}$ seasons. The opposite was the right regarding the content of total phenols which was significantly reduced by the various treatments employed in such trial to reach the minimum also by the combined treatments, especially that of SBG at $3 \mathrm{ml} / 1+\mathrm{K}-\mathrm{A}$ at $1 \mathrm{ml} / 1$ which reduced such parameter to $0.011 \mathrm{mg} / 100 \mathrm{~g}$ f.w. in the two seasons against 0.020 and 0.023 $\mathrm{mg} / 100 \mathrm{~g}$ f.w. for control in the $1^{\text {st }}$ and $2^{\text {nd }}$ seasons, respectively. This may explain the reason whereby these combinations were always dominant over the other treatments. In this concern, Kenneth (1979) reported that the total control of plant growth is vested not in a single hormonal type-that of auxin, but is shared by several specially auxins, cytokinins, gibberllins and ethylene, and this is further subjected to modification by certain naturally occurring inhibitors, namely phenols, flavonols and absicsic acid, which have been known to modify the activity of IAA oxidase and might therefore be acting on growth and production by way of changes in endogenous auxin levels. Moreover, Weaver (1972) suggested that the naturally occurring growth inhibitors in the plants are phenyl compounds, including phenols, benzoic acid and phenolic flavonoids. They probably play role in the control of growth and development of the plant in conjunction with the other hormones.

From the aforementioned results, it is recommended to spray the verdure of seashore paspalum turf with a combination of super bluegreen liquid fertilizer at $3 \mathrm{ml} / 1+$ Kalsin-A one at $1 \mathrm{ml} / \mathrm{l}$, five times with one month interval for the best growth performance, coverage and colour.

\section{REFERENCES}

A.O.A.C. (1990). Association of Official Agricultural Chemists "Official Methods of Analysis of the association of Official Agricultural Chemists". $15^{\text {th }}$ Ed., Arlington, Virginia 22201:877-878.

Cottenie, A.; Verloo, M.; Kiekan, L.; Velghe, G. and Comerlynck, R. (1982). Chemical Analysis of Plants and Soils. Laboratory of Analytical and AgroChemistry. State Univ., Ghent-Belgium, P. 45 .

Datir, R.B.; Apparao, B.J. and Laware, S.L. (2012). Application of amino acid chelated micronutrients for enhancing growth and productivity in Chili (Capsicum annum L.). Plant Sciences Feed, 2(7):100-105.

Dubois, M.; Smith, F.; Illes, K.A.; Hamilton, J.K. and Rebers, P.A. (1966). Colorimetric mehod for determination of sugars and related substances. Ann. Chem., 28(3):350-356.

Duncan, D.B. (1955). Multiple range and multiple F. Tests, Biometrics, 11:1- 24.

El-Sayed, Boshra A. (2012). Improving growth and quality of seashore paspalum turf by actosol and oligo-X. J. Biol. Chem. \& Environ. Sci., 7(2):77-87.

Huxley, A.; Griffiths, M. and Levy, M. (1992). The New Royal Hort. Society Dictionary of Gardening. The Stockton Press, 257 Park Avenue South, New York, N. Y. 10010, USA, vol. 3, 790 pp.

Jackson, M.H. (1973). Soil Chemical Analysis. Prentice-Hall of India Private Limited M-97, New Delhi, India, 498pp.

Kenneth, V.T. (1979). Physiology of Plant Growth and Development. B. Willkins TaTa, McGraw-Hill Publishing Co. Ltd., New Delhi. 
Mahdi, M.Z. (1953). The Influence of Management on Botanical Composition and Quality of Turf. Ph.D. Thesis, Fac. Agric., California Univ., Los Angeles, USA.

Mead, R.; Curnow, R.N. and Harted, A.M. (1993). Statistical Methods in Agriculture and Experimental Biology. $2^{\text {nd }}$ Ed., Chapman \& Hall Ltd., London, 335 pp.

Mengel, K. and Kirkby, E.A (1979). Principals of Plant Nutrition. International Potash Inst., P.O. Box CH3048, Worklayfen, Bern, Switzerland, $2^{\text {nd }}$ Ed. pp. 593.

Morton, J.F. (1974). Salt tolerant silt grass (Paspalum vaginatum Swartz). Proceeding of the Florida State Hort. Sci., Miami Univ., USA, 86: 482-490.

Peacock, C.H.; Daniel, P.F. and Dudekanic, A.E. (1985). A comparison of sod type and fertilization during turf establishment. HortSci., 20(1):108-109.

Pompeianoa, A.; Gianninib, V.; Gaetanic, M.; Vitac, F.; Guglielminettic, L.; Bonarib, E. and Volterranic, M. (2014). Response of warm-season grasses to $\mathrm{N}$ fertilization and salinity. Scientia Hort., 177(2):92-98.

Pregl, F. (1945). Quantitative Organic Micro-Analysis $4^{\text {th }}$ Ed., J \& A., Churchill, Ltd., London, P. 203-209.
Rimia, F.; Macolinoa, S.; Richardson, M.D.; Karcherb, D.E. and Leinauerc, B. (2013). Influence of three nitrogen fertilization schedules on bermudagrass and seashore paspalum: I. Spring green-up and fall colour retention. J. Crop Science, 53(3):1161-1167.

Saric, M.; Kastrori, R.; Curic, R.; Cupina T. and Geric, I. (1967). Chlorophyll Determination. Univ $U$ Noven Sadu Parktikum is Fiziologize Biljaka, Beogard, Haucna, Anjiga, p.215.

SAS Institute Program (1994). SAS/STAT User`s Guides Statistics. Vers. 6.04, $4^{\text {th }}$ Ed., SAS Institute Inc., Cary, N.C., USA.

Trenholm, L.E. and Unruh, J.B. (2009). Central Florida fertilizer trials, on "Empire" Zoysiagrass and "Pensacola" bahiagrass. Proc. Fla. State Hort. Soc., 122:386-389.

Weaver, R.J. (1972). Plant Growth Substances in Agriculture. W.H. Freeman and Company, San Francisco, 588 pp.

William, M.; Chichlilo, P.; Clifford, P.A. and Reynolds, M. (1965). Official Methods of Analysis of the Association of Official Agriculture Chemists, $10^{\text {th }}$ Ed., Washington D.C. 20044:52-55.

\footnotetext{
التسميد الورقي بالأسمدة التجارية السائلة لتحسين نمو وجودة مسطح الباسبالم

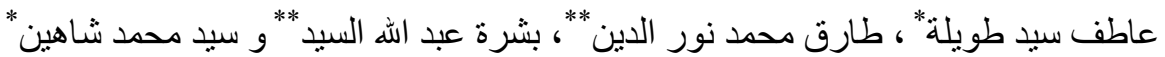

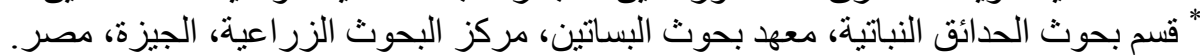

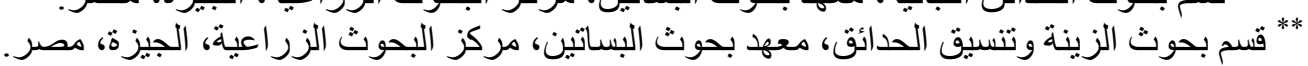

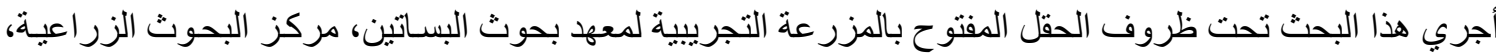

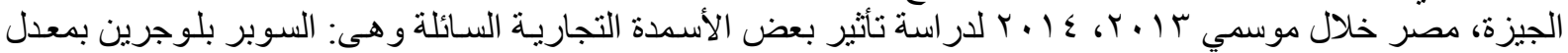

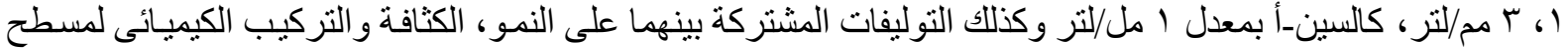

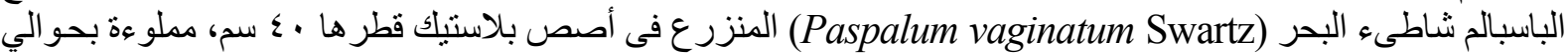

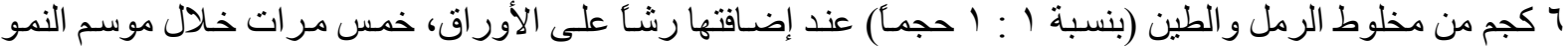

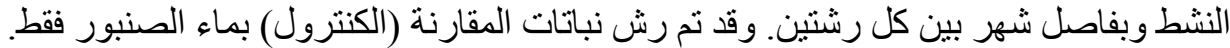

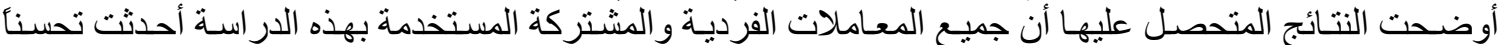

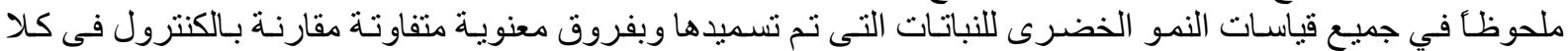

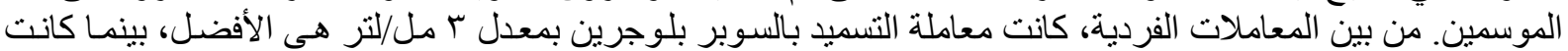




\section{A.S. Tawila et al.}

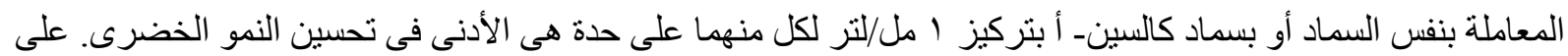

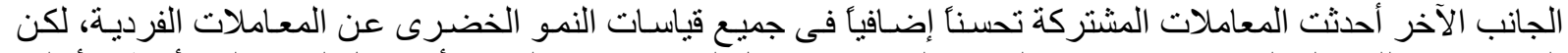

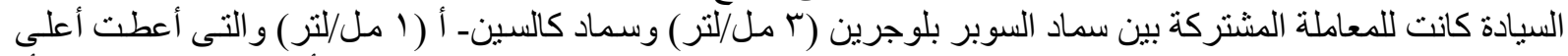

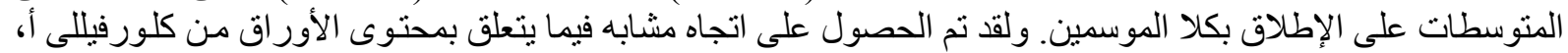

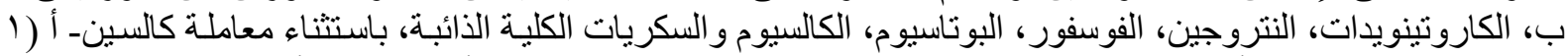

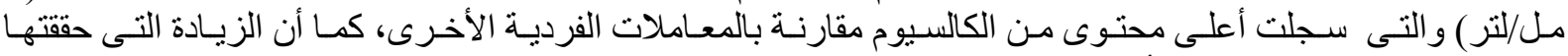

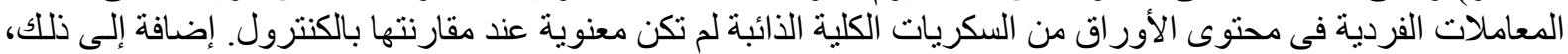

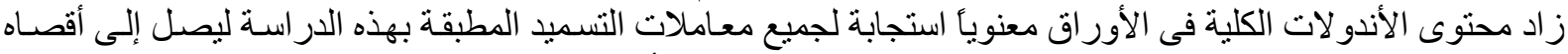

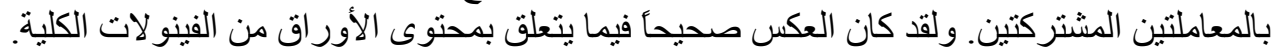

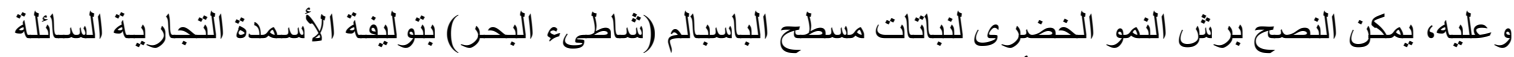

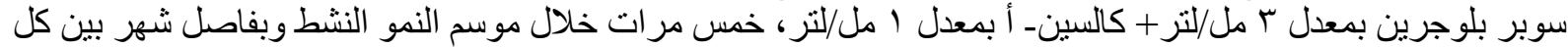

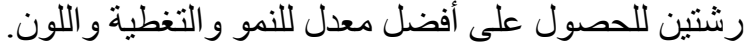

